\title{
PRELIMINAR: DERIVAS DERRIDIANAS DE LA LITERATURA
}

\author{
Cristina de PERETTI \\ UNED \\ mperetti@fsof.uned.es
}

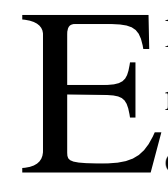
1 interés de Jacques Derrida por lo que solemos denominar «literatura» es notorio desde sus primeros textos hasta los últimos. A lo largo de esos más de cuarenta años, no sólo son frecuentes los artículos e incluso los libros que Derrida dedica a una serie de literatos como son, por no citar sino a algunos de ellos, Mallarmé, Rousseau, Blanchot, Celan, Artaud, Genet, Ponge, Joyce o Kafka -escritores a varios de los cuales están a su vez dedicados algunos de los ensayos que aquí se presentan- sino que, además, en buena parte de los textos de Derrida que pueden considerarse más «estrictamente filosóficos» las alusiones literarias nunca dejan de ser frecuentes. Ese es el caso, por ejemplo, de la «Introducción» que Derrida escribe para su propia traducción al francés del Origen de la geometría de Husserl en la que, junto al gran pensador de la fenomenología, Derrida no duda en deslizar varias referencias a Joyce o a Poe; sin olvidar el caso, el más emblemático sin duda, de Glas en donde a lo largo de todo el libro, Genet, escritor homosexual de los bajos fondos, reta desde su propia columna a Hegel, el gran pensador del saber absoluto.

Para Derrida, la filosofía y la literatura no dejan pues de contaminarse nunca mutuamente -lo cual no significa, como a veces se le ha querido reprochar, que Derrida no las diferencie entre sí y las convierta, sin más, en un totum revolutum-. El estudio de una serie de obras literarias le permite así abordar a Derrida todo un conjunto de cuestiones que la filosofía nunca se ha permitido pensar o, por decirlo de otra forma, siempre se ha resistido a pensar. Ese es el caso, por ejemplo, de esa diseminación indecidible e inapresable que afecta al sentido de todo texto; o el caso del estilo, de la singularidad, a saber, de lo que Derrida denomina el «idioma» de cada escritura; o el caso de algunos motivos estratégicos del texto como pueden ser, entre otros, el concepto 
de texto precisamente, o de obra, así como el título o la firma, o las relaciones de todos ellos con el derecho, etc.

Por su parte, la reflexión acerca de ciertas problemáticas que atañen no sólo al ámbito filosófico sino al terreno, más amplio, de lo que podríamos denominar «las ciencias humanas»-derecho, psicoanálisis, etc.-, problemáticas como son, por ejemplo, el secreto, la mentira, el testimonio, el perdón, etc., cobran a su vez, desde el espacio de la escritura literaria, unas dimensiones insospechadas e inauditas en la medida en que la literatura, concebida por Derrida como «derecho a decirlo todo», deja patente la imposibilidad de distinguir con todo rigor entre la realidad y la ficción o, por decirlo una vez más con terminología derridiana, deja patente la indecidibilidad entre ambas. 